\title{
Fraud transactions revealing as phase of financial analysis in Forensic Economic Examination
}

\author{
Irina Astrakhantseva ${ }^{1, *}$, and Roman Astrakhantsev ${ }^{2}$ \\ ${ }^{1}$ Ivanovo state University of chemistry and technology, Sheremetev avenue, 7, 153000 Ivanovo, \\ Russia \\ ${ }^{2}$ National Research University Higher School of Economics, Myasnitskaya Str., 20, 101000 Moscow, \\ Russia
}

\begin{abstract}
The scientific research study is about financial methodology analysis improving in the framework of forensic economic examination. The objective bankruptcy date is one of the issues within the forensic examination. The authors propose to supplement the classical financial analysis with a special section, which analyzes transactions for compliance with market conditions, identifies schematic and fictitious transactions, and also determines the degree of their impact on the occurrence of property insufficiency and signs of bankruptcy. The author's classification of possible schematic transactions, as well as methods for establishing the fact of compliance with the market situation are proposed. As the criterion for the maximum permissible deviations of transaction values from market values, it is proposed to use a value in an amount not exceeding the change in values by more than two times. The technical assets identified as a result of fictitious transactions are proposed to be deducted from the market value of assets when calculating the net assets of the organization, which will allow the most correct determination of the objective bankruptcy date.
\end{abstract}

\section{Introduction}

In the National Security Strategy [1], the criminalization of economic and financial relations remains among the main strategic threats. This is also stated in the Strategy of the Economic Security of the Russian Federation through to 2030 [2], that the high level of criminalization and corruption in the economic sphere and the significant share of the shadow economy remain. Therefore, the task is to prevent deliberate bankruptcies, prevent, prevent raider seizures and other illegal actions in the financial and economic sphere, as well as create conditions that exclude the possibility of splicing the interests of business officials and representatives of state bodies.

According to information presented on the official website of the Ministry of Internal Affairs of the Russian Federation [3], in January-October 2020, 96,124 economic crimes were registered. The material damage (for completed and suspended criminal cases of an economic nature amounted to 302 billion rubles, including tax: 71 billion rubles. The data of

*Corresponding author: i.astrakhantseva@mail.ru 
the Ministry of Internal Affairs of the Russian Federation indicate an increase in crimes, representing only the upper part of the iceberg. The high level of latency of financial and economic crimes is due to the difficulty of proving them due to the specificity and uniqueness of actions, including through the use of modern information technologies.

Under these circumstances, the requirements for analytical work in the detection and investigation of crimes are increasing, namely, it is necessary to improve the existing methodological approaches to financial analysis when using one of the important means of proof used by law enforcement officers, the forensic financial and economic examination.

\section{Materials and Methods}

The forensic economic examination is required for investigating of a wide range of crimes, where accounting and financial information is closely interconnected with the circumstances that are subject to proof [4]. One of the stages of conducting a financial and economic examination is a financial analysis of the activities of an economic entity. The financial analysis is a study of the main indicators of organization financial status and performance.

The selection of the financial analysis method depends both on the question posed to the expert and on the specifics of the studied organization's activities. In order to determine the financial status of organizations, experts most often use complex methods of the organization financial analysis which include: analysis of the organization property and capital using horizontal and vertical analysis, assessment of financial stability, solvency, business activity, profitability based on coefficient analysis, as well as determining the likelihood of bankruptcy of the organization based on integral (rating) methods.

Techniques for analyzing of commercial organization financial status are reflected in the works of such foreign (E. Helfert, D. Stone, K. Hitching, L.A. Bernstein, J. Richard, etc.) and domestic scientists (A.D. Sheremet, V.V. Kovalev, G.V. Savitskaya, O.V. Efimova, V.V. Bocharova, N.A. Dontsova, etc.). Scientists and specialists consider the main disadvantage of all methods is the absence of differences in the recommended values of relative indicators for enterprises in various sectors of the economy. In domestic literature, there is a lack of uniform formulas for calculating indicators and the presence of synonyms for many coefficients.

\section{Results and Discussion}

Within the financial and economic examination, on the basis of financial analysis, issues regarding the determination of the moment (period) of the onset of actual (objective) bankruptcy, analysis of counterparties by economic and legal criteria, analysis of cash flows and commodity flows, identification of transactions and operations that influenced financial status, determining the degree of influence of "schematic" transactions on the occurrence of property insufficiency and signs of bankruptcy, and other issues can be resolved. Therefore, the authors suggest, after the "classic" component of financial analysis (horizontal and vertical analysis of financial statements, coefficient analysis, rating and integral methods, factor analysis), to conduct a special section of financial analysis, which consists of the following stages:

- Calculation of net assets value at book and market value;

- Ratio analysis based on market ratios;

- Calculation of return on equity multifactor model based on market ratios;

- Analysis of transactions, requiring close attention of the investigating organization.

The structural-dynamic reporting analysis will assess the general status and identify the "sick" points at the initial analysis stage. The coefficient analysis will allow a forensic expert 
to assess the activities of the organization from the standpoint of liquidity, profitability, solvency and business activity. Rating methods are often used to determine the likelihood of bankruptcy, and factor analysis allows you to identify specific transactions (factors) that led to the emergence of insufficient property.

Calculation of net assets, especially at market value, allows an expert, within the forensic economic examination, to determine the date of the onset of an objective bankruptcy of the organization (the moment of transition of the market value of net assets from positive to negative). Provided the forensic expert shall determine a series of transactions related to the withdrawal of assets, replacement of liquid assets with technical ones, which led to the organization's insolvency. This stage of analysis is characterized by extensive analytical work to identify "schematic" and dubious transactions, the degree of their influence on the occurrence of property insufficiency and signs of bankruptcy.

The negative impact of non-market transactions on the financial status of organizations lies in their inefficiency. As a rule, such transactions are associated with an increase in the debt of a legal entity or with the withdrawal of property. The authors propose a scheme of the main transactions that must be analyzed for compliance with the conditions, as well as methods for establishing the fact of compliance or non-compliance with the market situation. When describing the criteria for maximum permissible deviations, a critical value is used in a size not exceeding the change in values by more than two times [5]. Among the main business processes that are most at risk of non-market transactions are sales activities, purchasing activities, inventory management, distortion of reporting data, personnel management, charity and fundraising and placement of funds.

Significant deviations of actual indicators from similar forecast values, the presence of unexplained shortages, the lack of influence of significant transactions on financial indicators, unexplained, including excessive volumes of purchases of raw materials and materials, unreasonable expenses, atypical for the company's activities, as well as excessive fines and penalties provided for by existing contracts shall be used as signals evidencing the actions that resulted in the company financial status worsening. Below is the author's classification of possible schematic transactions, as well as methods for establishing the fact of compliance with the market situation.

Table 1. Classification of artificial transactions

\begin{tabular}{|c|c|}
\hline $\begin{array}{ll}\text { Possible } & \text { artificial } \\
\text { transactions } & \\
\end{array}$ & Methods for determining the transaction conformance with market conditions \\
\hline \multicolumn{2}{|l|}{ Asset management } \\
\hline \multirow{4}{*}{$\begin{array}{l}\text { Sale of fixed assets, } \\
\text { excluding intra-group } \\
\text { transactions }\end{array}$} & $\begin{array}{l}\text { Calculation of the realizable fixed assets market value as of the transaction date and } \\
\text { comparison with the contract price }\end{array}$ \\
\hline & Analysis of the need to use realizable fixed assets in the production process \\
\hline & Counteragent underwriting \\
\hline & Analysis of cash flows obtained from the sale of assets \\
\hline $\begin{array}{l}\text { Gratuitous transfer of } \\
\text { fixed assets }\end{array}$ & $\begin{array}{l}\text { Analysis of the need to use the transferred fixed assets in the organization production } \\
\text { process }\end{array}$ \\
\hline \multirow{6}{*}{$\begin{array}{l}\text { Transactions on fixed } \\
\text { assets acquisition }\end{array}$} & Analysis of the need to purchase fixed assets for the activity implementation \\
\hline & $\begin{array}{l}\text { Determining the possibility of acquiring assets as of the transaction date (availability of free } \\
\text { monetary funds) }\end{array}$ \\
\hline & Compliance of the acquired assets with the investigated enterprise type of activity \\
\hline & $\begin{array}{l}\text { Assessment of the market value of the acquired fixed assets and the price under the } \\
\text { contract }\end{array}$ \\
\hline & Post-transaction cash flow study \\
\hline & $\begin{array}{l}\text { Analysis of the initial assets cost formation and the procedure for depreciation } \\
\text { calculation }\end{array}$ \\
\hline
\end{tabular}


Table 1. Continued

\section{Contributions to the} authorized capital of third-party companies Purchase of securities at artificially inflated prices Transactions on the acquisition of illiquid assets, including illiquid securities, rights of claim

Provision of credits and loans to third-party individuals and legal entities not forming a group of companies with the studied organization Conclusion of assignment agreements

Evaluation of participatory interest market value

Evaluation of securities' market value

Analysis of the need to acquire assets in order to conduct activities

Determining the possibility of acquiring assets as of the transaction date (availability of free monetary funds)

Compliance of the acquired assets with the investigated enterprise type of activity

Analysis of purchased securities for liquidity, analysis of the possibility of making payments on them

Post-transaction cash flow study

Analysis of the market return level for similar transactions in the market

Determining the possibility to provide credits and loans as of the transaction date (availability of free monetary funds)

Determination of the borrower's solvency level as of the transaction date

Calculation of the pledged objects market value as of the transaction date

Analysis of the market return level under credit agreements similar to the credit to be assigned within the assignment agreement

Assessment of the borrower's solvency, credit repayment schedule

Assessment of the assignee's solvency

Analysis of the liquidity of assets acquired under the exchange agreement

Repayment of credits issued by the company through compensation

The sale of receivables at a price significantly lower than the book value, or writing it off

Repayment of accounts receivable by purchasing illiquid debt securities

Issuance of accountable funds without appropriate documents Conclusion of exchange agreements

Artificial cash balance

Inconsistency between assets value and their actual balance

\section{Liability management}

\section{Dividend payments}

Repayment of credits taken by the company through compensation Obtaining of credit or loan on non-market conditions

Non-payment of wages, resulting in an increase in accounts payable
Assessment of the borrower's solvency, credit repayment schedule, the need to use compensation

Study of the counterparty's solvency, making payments to repay the debt

Study of the counterparty's solvency, making payments to repay the debt

Analysis of the liquidity of acquired debt securities

Assessment of the need to use funds by accountable persons

Establishing the possibility of issuing accountable funds (availability of a sufficient amount of free monetary funds)

Assessment of the assets market value involved in the exchange

Analysis of the liquidity of assets acquired under exchange agreement

Establishing the correspondence of documentation data and the actual cash balance at the cash desk

Assessment of the market value of assets in stock and in production

Needs assessment for the amount of assets available in the warehouse and in production

Study of the ratio of paid dividends and the need for equity capital

Analysis of the need to use the transferred objects in the production process

Assessment of the company's solvency and the possibility of credit repayment, the schedule of credit payments, the need to use compensation

Analysis of the need to use additional borrowed funds in the production process

Assessment of the company's solvency as of the credit obtaining date

Determination of the market level of profitability for similar transactions in the market

Analysis of cash flows received from the assets sale

Establishing the fact of wage arrears

Study of the availability of funds sufficient to make wage payments and the possibility of sending them towards payment 
Table 1. Continued

\begin{tabular}{|c|c|}
\hline \multirow{2}{*}{$\begin{array}{l}\text { Failure to pay tax and } \\
\text { other mandatory } \\
\text { payments }\end{array}$} & Study of the payment schedule for the payment of tax and other obligations \\
\hline & Analysis of the organization's solvency during the period of non-payment \\
\hline \multirow{2}{*}{$\begin{array}{l}\text { Conclusion of contracts } \\
\text { for the supply of goods, } \\
\text { provision of works and } \\
\text { services on deliberately } \\
\text { unfavorable terms and } \\
\text { conditions }\end{array}$} & $\begin{array}{l}\text { Study of the compliance of the contract conditions, including terms, fines, penalties, } \\
\text { delivery terms, market conditions in relation to similar contracts }\end{array}$ \\
\hline & $\begin{array}{l}\text { Assessment of the possibility of fulfilling the contract terms and conditions as of the } \\
\text { conclusion date }\end{array}$ \\
\hline \multicolumn{2}{|l|}{$\begin{array}{l}\text { Income and expense } \\
\text { management }\end{array}$} \\
\hline $\begin{array}{l}\text { Supply of goods, } \\
\text { performance of works } \\
\text { and services under non- } \\
\text { market conditions }\end{array}$ & $\begin{array}{l}\text { Study of the compliance of the contract terms and conditions, including the contract } \\
\text { price with market conditions }\end{array}$ \\
\hline \multirow{4}{*}{$\begin{array}{l}\text { Purchase of feedstock } \\
\text { and materials under non- } \\
\text { market conditions }\end{array}$} & Analysis of the market level of prices for similar feedstock and materials \\
\hline & $\begin{array}{l}\text { Establishing the need to purchase feedstock and materials in the scope provided } \\
\text { under the contract }\end{array}$ \\
\hline & $\begin{array}{l}\text { Determination of difference between the funds allocated for the purchase of } \\
\text { feedstock and materials and the market value of feedstock and materials }\end{array}$ \\
\hline & Analysis of the further movement of funds transferred as payment \\
\hline \multirow{3}{*}{$\begin{array}{l}\text { Conclusion of rental } \\
\text { agreements }\end{array}$} & Estimation of market rental rates and comparison with contractual rental rates \\
\hline & Analysis of the need to rent premises \\
\hline & $\begin{array}{l}\text { Study and comparison of the leased facilities' characteristics and the needs of } \\
\text { production activities }\end{array}$ \\
\hline \multirow{2}{*}{$\begin{array}{l}\text { Payment of salaries and } \\
\text { bonuses to the } \\
\text { company's management } \\
\text { not corresponding the } \\
\text { average monthly level }\end{array}$} & $\begin{array}{l}\text { Analysis of the possibility of making payments to management (availability of free } \\
\text { monetary funds) }\end{array}$ \\
\hline & Compliance of the paid wages' level with production volumes \\
\hline \multirow{4}{*}{$\begin{array}{ll}\text { Other expenses of the } \\
\text { organization } & \text { not } \\
\text { corresponding } & \text { the } \\
\text { average market level }\end{array}$} & The need for expenses \\
\hline & $\begin{array}{l}\text { Establishing the conformance of the level of expenses associated with the payment } \\
\text { of interest on loans with market conditions }\end{array}$ \\
\hline & $\begin{array}{l}\text { Assessment of the market value of assets, the sale of which resulted in a loss on sale; } \\
\text { The need to use assets in the production process }\end{array}$ \\
\hline & Study of primary documentation and accounting registers \\
\hline \multirow{2}{*}{$\begin{array}{l}\text { Establishment of } \\
\text { parallel business with an } \\
\text { identical name by } \\
\text { management }\end{array}$} & Production level analysis \\
\hline & $\begin{array}{l}\text { Establishing the fact of the coincidence of the details of the new organization, such } \\
\text { as name, type of main activity }\end{array}$ \\
\hline $\begin{array}{l}\text { Other } \\
\text { expenses }\end{array}$ & Study of the illegal entrepreneurial activity without registration \\
\hline
\end{tabular}

In the result of the analysis, transactions should be identified that do not correspond the market conditions prevailing at the date of their conclusion. Particular attention should be paid to transactions with related parties, transit transactions (crediting funds from various counterparties with their further transfer in a short time, transactions that do not lead to the creation of a taxable base), transactions that do not make economic sense for the company. Analysis of the purity and marketability of transactions includes the study of contracts concluded by the organization. Primarily, the consistency of the very subject of the contract shall be examined. In executing technical transactions, contracts are usually identical in text and form and have only minor differences. The study of consignment notes, invoices, or rather their presence, compliance with these agreements and the absence of errors, corrections, inaccuracies and other distortions in the specified documents, also helps to assess the correctness of the transactions. The mistakes made by the management in the process of carrying out economic activities also negatively affect the performance of organizations. Among such errors, one can single out the fact of the introduction of penalties against the 
investigated company due to delay in payment or delivery, as a result of which it becomes necessary to pay fines, penalties and forfeits.

The date of objective bankruptcy is determined when calculating the market value of net assets. The identified technical (fictitious) assets as a result of fictitious transactions must be deducted from the market value of the assets accepted for calculation when calculating the net assets of the organization (Fig. 1).

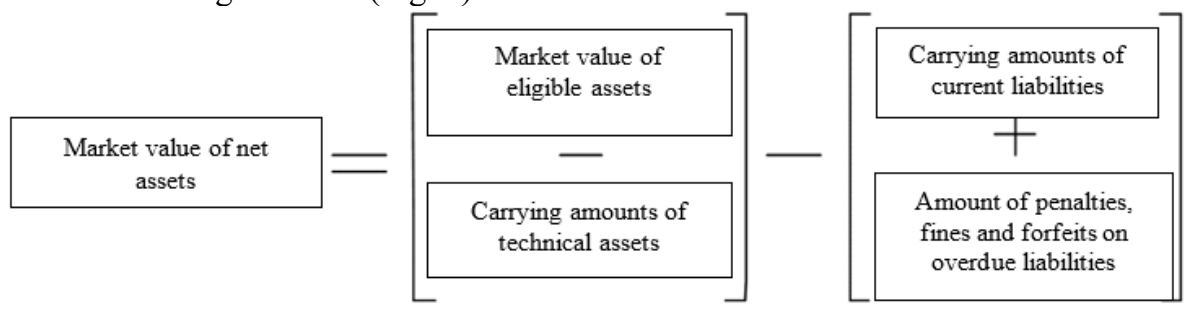

Fig. 1. Calculation of net assets market value for establishing the date of objective bankruptcy.

In the result of calculations, the carrying amounts and market values of net assets may differ materially. However, it is the market value, analyzed in dynamics, that makes it possible to determine the real date when the value of liabilities exceeded the value of the property and the organization lost the ability to pay off existing debts (Fig. 2)

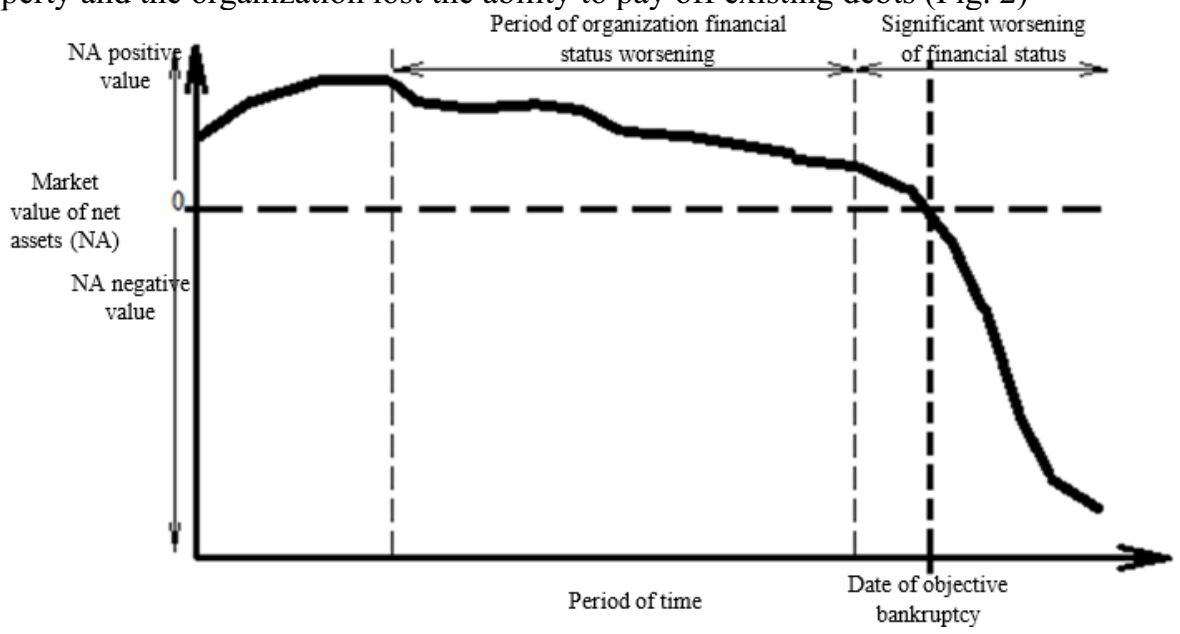

Fig. 2. Determination of date of objective bankruptcy on the basis of the analysis of net assets market value dynamics

It shall be noted that in analyzing net assets, it is worth considering not only their market value, but also their quality and structure. Even being in the area of positive values and having an upward growth rate, the reasons for such dynamics can be both positive and negative for the activities of the studied organization. If the reason for the value growth of net assets is an increase in the value of inventories and receivables, with a simultaneous decrease in their liquidity, this situation cannot indicate the positive dynamics of the company's development.

Transactions related to the purchase or sale of fixed assets, as a rule, entail a change in the profitability ratios, the value of the net working capital, the turnover ratios. Purchase of raw materials and supplies is mainly associated directly with changes in the turnover of inventories, as well as the absolute liquidity ratio. The acquisition or repayment of receivables is reflected in the change in the turnover ratios of this asset, as well as in the change in liquidity ratios. The exercise of rights (claims) affects a whole range of financial indicators, among which indicators of financial stability, profitability and liquidity ratios can 
be distinguished. Contributions to the authorized capital of third-party organizations entail a decrease in the turnover and liquidity ratios. The provision of a loan has a negative effect on the value of the absolute liquidity ratio with a simultaneous increase in the equity capital flexibility ratio. The value of the ratios of financial stability, profitability and liquidity, as a rule, is negatively affected by the payment of dividends. Obtaining of credit for the organization is associated, first of all, with a decrease in financial stability indicators, on the other hand, this leads to an increase in liquidity and, in the future, with proper disposal of the funds received, it can have a positive effect on profitability indicators.

Thus, conducting a high-quality financial analysis within the framework of forensic economic examinations is aimed at forming an objective opinion about the financial condition of the organization. Due to the fact that various factors can affect the state of the organization, in the framework of the forensic examination, attention should be paid to such factors as the compliance of the transactions with market conditions, the influence of the group of companies, as well as the dynamics of changes in the market value of net assets.

\section{Conclusions}

1. The current stage of social and economic development of society requires the improvement of analytical work in the detection and investigation of crimes, in particular, the development of methods for the financial analysis of organizations in the framework of forensic economic examinations. all the features of its activities.

2. In view of the fact that various factors can influence the state of the studied organizations, it is recommended to add a special section of financial analysis in the framework of improving the methodology for conducting financial analysis in a trial, which involves calculating financial ratios, net assets, and analyzing the return on equity on the basis of market rather than balance ratios.

3. One of the most important stages of forensic financial analysis will be the analysis of transactions of the investigated organization, which requires close attention,. It is non-market technical and fictitious transactions that are the basis for the deliberate and fictitious bankruptcy of the organization. The classification of such schematic transactions and methods of establishing the fact of compliance with the market situation is given. As the maximum permissible deviations, a critical value is used in a size that does not exceed the change in values by more than two times.

4. In order to determine the date of the objective bankruptcy of the company, the analysis of the dynamics of net assets at market value, taking into account the value of technical assets in the balance sheet and possible liabilities (for economic sanctions) in the liabilities of the balance sheet, is subject to research, since it is the market value that will reflect the real ability of the organization to repay its debts.

5. A multifactorial study of the organization's activities considering the influence of transactions on various financial indicators, allows a multilateral analysis of the investigated enterprise. Such a study makes it possible to identify the main facts of economic activity that could cause a deterioration in the efficiency of the company, which is one of the tasks of conducting a forensic economic examination.

\section{References}

1. The decree of the President of the Russian Federation dated December 31, 2015 No. 683 "On National Security Strategy of the Russian Federation"

2. The decree of the President of the Russian Federation dated May 13, 2017 No. 208 "On Economic Security Strategy of the Russian Federation through to 2030” 
3. Official internet portal of the Ministry of Internal Affairs of the Russian Federation (MIA RF) https://мвд.pф/

4. S.V. Efimov? Forensic economical examination in criminal proceedings: practical reference guide, 16 (2020)

5. Resolution of Plenum of the Supreme Court of the Russian Federation dated June 23, 2015, 25, 93

6. I.A. Astrakhatseva, E.V. Balandina, Proceedings of higher education institutions, Economics, finance and production management series, 03(33), 3 (2017)

7. J.C. Van Horne, Fundamentals of financial management, 800 (2017)

8. V.V. Kovalev, O.N. Volkova, Analysis of business activities, 424 (2017)

9. G.V. Savitskaya, Integrated analysis of enterprise business activities: Textbook, 608 (2020)

10. E.R. Rosinaskaya, Forensic examination in civil, arbitration, administrative and criminal proceedings: monograph, 4, 576 (2020)

11. E. Helfert, Financial analysis tools and techniques, 663 (2015)

12. Hugh Grove, Tom Cook, Eric Streeper, Greg Throckmorton, Journal of forensic \& investigative accounting, 2(2) 